University of Nebraska - Lincoln

DigitalCommons@University of Nebraska - Lincoln

Faculty Publications: Department of Entomology

2020

Description of a New Species of Gymnetis Macleay (Coleoptera: Scarabaeidae: Cetoniinae: Gymnetini) from Colima, Mexico

\author{
Brett Ratcliffe \\ University of Nebraska - Lincoln, bratcliffe1@unl.edu \\ Guillermo Nogueira \\ Universidad Aut'onoma de Guadalajara, gnogalg57@yahoo.com.mx
}

Follow this and additional works at: https://digitalcommons.unl.edu/entomologyfacpub

Part of the Entomology Commons

Ratcliffe, Brett and Nogueira, Guillermo, "Description of a New Species of Gymnetis Macleay (Coleoptera: Scarabaeidae: Cetoniinae: Gymnetini) from Colima, Mexico" (2020). Faculty Publications: Department of Entomology. 857.

https://digitalcommons.unl.edu/entomologyfacpub/857

This Article is brought to you for free and open access by the Entomology, Department of at DigitalCommons@University of Nebraska - Lincoln. It has been accepted for inclusion in Faculty Publications: Department of Entomology by an authorized administrator of DigitalCommons@University of Nebraska - Lincoln. 


\title{
Description of a New Species of Gymnetis Macleay (Coleoptera: Scarabaeidae: Cetoninnae: Gymnetini) from Colima, Mexico
}

\author{
BRetT C. RatClifFe \\ ORCID \#0000-0002-0589-8791 \\ Systematics Research Collections, University of Nebraska State Museum \\ W-436 Nebraska Hall, University of Nebraska \\ Lincoln, NE 68588-0514, USA \\ bratcliffe1@unl.edu \\ AND \\ Guillermo Nogueira \\ ORCID \#0000-0003-2899-8928 \\ Facultad de Ciencia y Tecnología, Universidad Autónoma de Guadalajara \\ Apdo. Postal 1-440, Guadalajara, Jalisco 45129, MEXICO \\ gnogalg57@yahoo.com.mx
}

\begin{abstract}
Gymnetis pedroreyesi Ratcliffe and Nogueira, new species, is described from the state of Colima, Mexico. The description is accompanied by illustrations, a diagnosis to distinguish it from similar species, observations on natural history, and a key to the 12 Mexican species of Gymnetis MacLeay, 1819.
\end{abstract}

\section{Resumen}

Gymnetis pedroreyesi Ratcliffe y Nogueira, nueva especie, es descrita del Estado de Colima, México. La descripción es acompañada por ilustraciones, diagnosis para distinguirla de especies similares, observaciones y características de su hábitat y una clave para las 12 especies mejicanas de Gymnetis MacLeay, 1819.

Key Words: taxonomy, flower chafer, Neotropical, scarab beetle, identification key

\author{
DOI.org/10.1649/0010-065X-74.1.109 \\ Zoobank.org/urn:lsid:zoobank.org:pub:ED4B45CE-CF75-4C06-B76D-2AECC8F4596F
}

\section{INTRODUCTION}

The genus Gymnetis MacLeay (Coleoptera: Scarabaeidae: Cetoniinae: Gymnetini) includes 56 species and four subspecies and was recently revised by Ratcliffe (2018). Nogueira ascertained that specimens he collected in Colima, Mexico, were new and contacted Ratcliffe to jointly describe this new species. With the addition of this species, there are now 12 species of Gymnetis in Mexico, and these are included in an identification key to the Mexican species presented herein.

\section{Material ANd Methods}

Label data are quoted verbatim in the text; a single slash (/) indicates a break between lines on the same label, and a double slash (//) indicates a different label on the same specimen. The key characters and species descriptions were based on the following characteristics: length from apex of pronotum to apex of elytra (the head may or may not be deflexed and, if measured, could give a misleading length); width across humeri; color and markings; interocular width (number of transverse eye diameters across the frons); form and sculpturing of the head, pronotum, elytra, and pygidium; form of the protibial and mesometasternal process; sculpturing and color of the abdominal sternites; and form of the male parameres. Punctures are considered simple unless otherwise noted. Minute punctures are generally not seen with $12.5 \times$ magnification but are easily seen with $50 \times$ magnification. Small punctures are easily seen with $12.5 \times$ magnification and can be seen with the naked eye. Large punctures are easily seen without the aid of instruments. Sparse punctures are characterized by numerous puncture diameters between them. Punctures moderate in density have 3-5 puncture diameters between them. Dense punctures have only 1-2 puncture diameters between them or less.

We use the phylogenetic species concept as outlined by Wheeler and Platnick (2000). This 
concept defines species as the smallest aggregation of (sexual) populations diagnosable by a unique combination of character states.

With Gymnetis species in particular, color and markings are extremely important characters, even though we typically consider them of lesser value because of their high intraspecific variability. These characteristics are listed first in the description, and then the physical traits of sculpturing for each of the body regions are given. Expressing in words the subtle shades of color or variably expressed, complex markings that often blend into one another on the pronotum and elytra is challenging and compounded by cultural differences in different countries for interpreting those color and pattern descriptors. Accordingly, the new species is illustrated in color. Velutinous refers to the soft, velvety surface on the pronotum and elytra, even though this surface seems to not be comprised of short, silky setae as implied by "velutinous". Opaque refers to a dull or non-shiny surface rather than a shiny surface. Diffuse refers to the fuzzy or soft edges of the dorsal markings present as opposed to hardedged or distinct markings. Smithe (1975) provided a simplified overview (with color swatches) of the more detailed volume of Ridgway (1912), and these works may be consulted for additional color information.

The collection codens used in this work are:

\section{BCRC}

BMNH

CMNC

GNGC

IEXA

IMECBIOCOL Colección Entomólogica del Instituto Manantlán de Ecología y Conservación de la Biodiversidad Centro Universitario de la Costa Sur, Universidad de Guadalajara, Guadalajara, Jalisco, Mexico

INBUNAM

MAMC

MNHN

NMPC

RACC
USNM

US National Museum of Natural History, Washington, DC, USA

WBWC William B. Warner Collection, Chandler, AZ, USA

ZMHU Museum für Naturkunde, Berlin, Germany

\section{Gymnetis pedroreyesi Ratcliffe and Nogueira, new species}

Zoobank.org/urn:lsid:zoobank.org:act:CC249E638548-486D-83B1-E6CCB0A56A83

(Figs. 1-8)

Type Material. Holotype male labeled: "MEXICO: COLIMA / COMALA, 700 m elev. / 7-8-July2000, / G. Nogueirra [sic] collector" and with our red holotype label. Allotype female with same data and our red allotype label. Paratypes with same data (10 males, 5 females), and same data except date of VI-30-20-2000 (2 males, 1 female), and VIII-312000 (2 males, 2 females). One additional male paratype labeled: "MEXICO: COLIMA, $651 \mathrm{~m}$ el / Comala, nr. Rancho Estrella / 7/8-VII-19, traps bananna [sic] / $19^{\circ} 18.631^{\prime} \mathrm{N} 103^{\circ} 44.720^{\prime} \mathrm{W} / \mathrm{R}$. Cunningham + G. Nogueira." Holotype and allotype deposited at INBUNAM. Paratypes are deposited at BCRC (2), BMNH (2), CMNC (1), GNGC (5), IEXA (1), IMECBIOCOL (1), MNHN (2), NMPC (1), RACC (2), USNM (2), WBWC (1), and ZMHU (2). Additional specimens with similar data are in MAMC and are currently unavailable and so not designated as paratypes.

Description. Holotype. Male (Figs. 1, 3). Length $16.8 \mathrm{~mm}$; width across humeri $9.8 \mathrm{~mm}$. Head: Frons velutinous smoky black with 2 short, broad, diffuse, gray spots on occiput. Surface with ocellate punctures moderate in size and density, mostly in front of gray spots. Clypeus velutinous smoky black; apex broadly truncate, narrowly reflexed. Interocular width equals 4.5 transverse eye diameters. Pronotum: Color mostly velutinous smoky black with diffuse pattern of dark gray and dirty yellow on anterior half and sides. Surface with small, sparse punctures along sides. Lateral margin with short marginal line broken at center, line not reaching anterior and posterior angles. Mesepimeron velutinous smoky black and narrowly shiny black on apex. Elytra: Color velutinous smoky black with irregularly dissected, yellow vittae on lateral margins. Surface with small, sparse punctures mesad of humerus, otherwise sculpturing obscured. Apices at suture subquadrate. Lateral marginal bead black. Pygidium: Color dark reddish brown. Surface completely, concentrically rugose, setigerous; setae minute, dense, black. Legs: Protibia tridentate, basal tooth removed. Venter: Metaventrite black, 

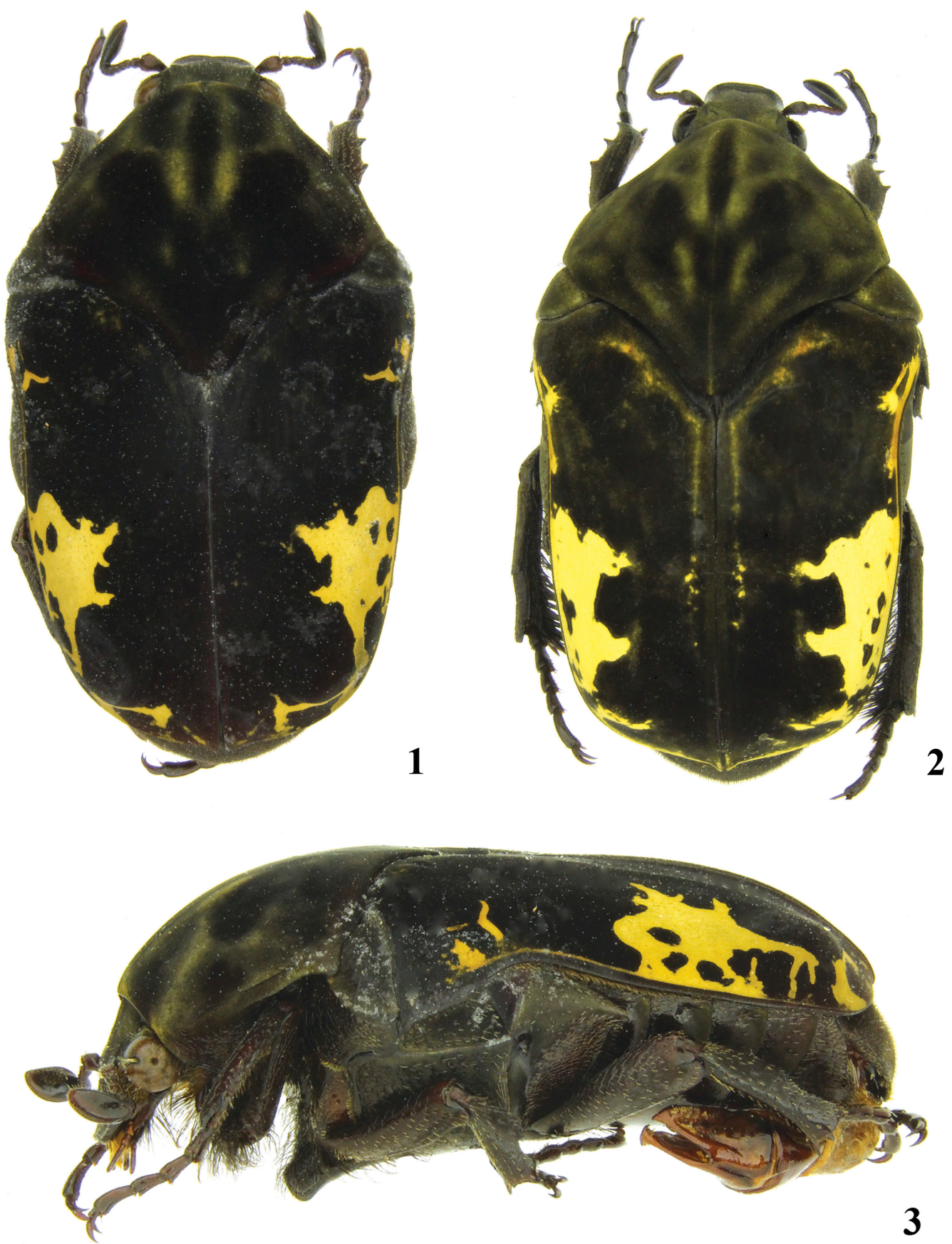

Figs. 1-3. Gymnetis pedroreyesi, new species. 1) Holotype, dorsal view; 2) Paratype; 3) Holotype, lateral view.

weakly shiny, and with sparse, black, crescentshaped, setigerous punctures on posterior half, anterior half rugose. Mesometasternal process, in lateral view, projecting forward and downwards from ventral axis of body at about $45^{\circ}$, apex subquadrate (Fig. 3). Metacoxa on posterolateral corner acutely recurved. Abdominal sternites shiny black on center, sides on lateral fourth with indistinct, gray bloom. Sternites 1-5 with small, dense, crescent-shaped punctures on anterolateral 

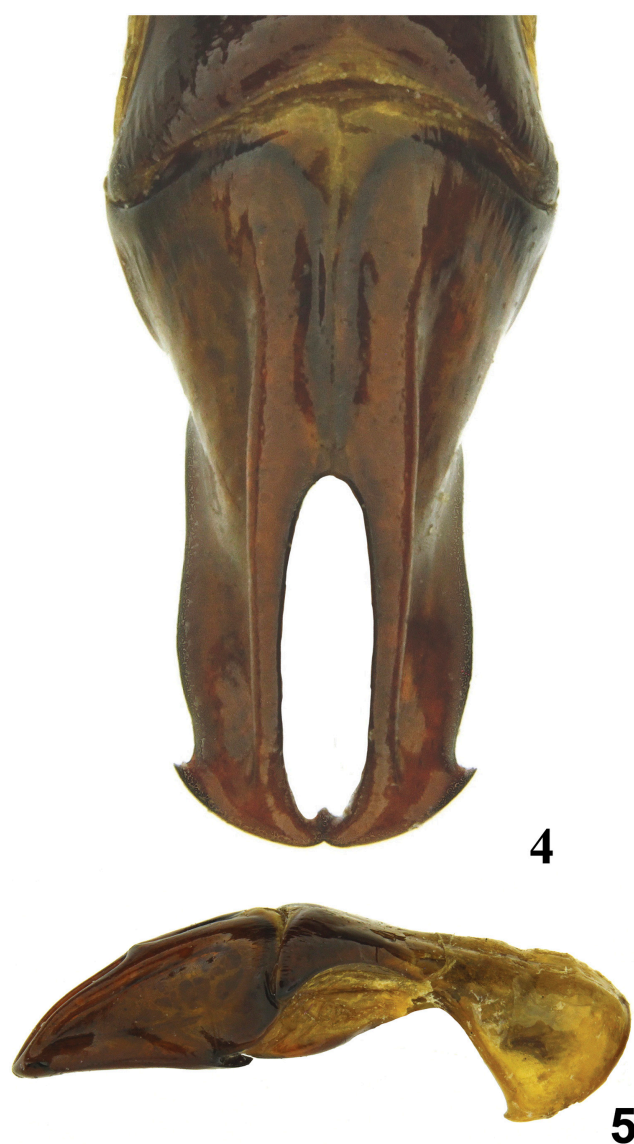

Figs. 4-5. Gymnetis pedroreyesi, new species, parameres. 4) Caudal view; 5) Lateral view.

corners. Setae on procoxae and mentum black. Parameres: In caudal view, form elongate, subrectangular, weakly flared on lateral margin, each apex flared laterally into small, sharp tooth (Fig. 4). In lateral

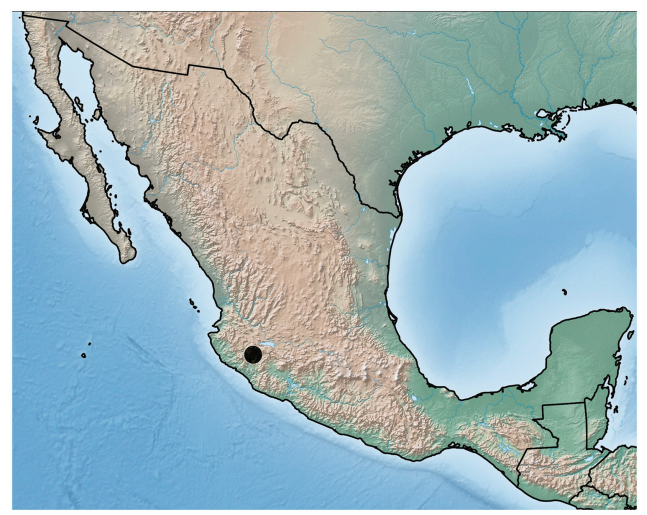

Fig. 6. Gymnetis pedroreyesi, new species, distribution in Mexico. view (Fig. 5), phallobase slightly longer than parameres.

Allotype. Female. Length $16.0 \mathrm{~mm}$; width across humeri $9.7 \mathrm{~mm}$. Differs from the holotype in the following respects: Head: Frons and clypeus velutinous black. Surface with ocellate punctures moderate in size and density. Interocular width equals 4.0 transverse eye diameters. Pronotum: Color velutinous black. Lateral margin with long, marginal line broken at center, line almost reaching anterior and posterior angles. Mesepimeron opaque black with small, shiny black spot on apex. Elytra: Color velutinous black with irregularly dissected, yellow vittae on lateral margins. Surface lacking punctures mesad of humerus. Pygidium: Color black. Venter: Metacoxa on posterolateral corner subquadrate. Abdominal sternites on sides lacking gray bloom. Sternites 1-5 with large, sparse punctures on lateral margins.

Variation. Males (Fig. 2) (14 paratypes). Length $16.5-19.7 \mathrm{~mm}$; width across humeri $10.0-13.0 \mathrm{~mm}$. Head: Color varies from smoky black to dark gray to brown to yellowish brown. Pronotum: Minor variations in the presence or absence of diffuse pattern of dark gray and dirty yellow. Lateral margin with long marginal line broken or not. Venter: Metaventrite with or without gray bloom. Abdominal sternites black to dark reddish brown.

Females (8 paratypes). Length 16.0-18.0 mm; width across humeri $9.0-11.0 \mathrm{~mm}$. Head: Color varies from smoky black to dark reddish brown. Elytra: Color varies from black to dark reddish brown. Pygidium: Color varies from black to dark reddish brown. Venter: Color varies from shiny black to shiny dark reddish brown. Metacoxa on posterolateral corner varies from subquadrate to acutely recurved.

Etymology. The specific epithet is named in honor of our recently deceased colleague and specialist of Passalidae, Pedro Reyes Castillo of the Instituto de Ecología in Xalapa, Mexico.

Distribution. Gymnetis pedroreyesi is known from Comala, Colima, Mexico.

Temporal Distribution. June (3), July (17), August (4).

Diagnosis. Gymnetis pedroreyesi is morphologically similar in its dorsal markings to some specimens of Gymnetis merops Ratcliffe and Gymnetis sallei Schaum, and nearly identical with Gymnetis poecila Schaum. Both $G$. merops and $G$. sallei have a yellow bead on the lateral margin of each elytron (black in $G$. pedroreyesi and $G$. poecila) and with at least some yellow or ochre on the male abdominal sternites (no yellow on the sternites of G. pedroreyesi and G. poecila). There is broad geographic separation between $G$. pedroreyesi, $G$. merops, and G. sallei; G. pedroreyesi is found in extreme southwestern Mexico, while G. merops is distributed in Peru, and G. sallei occurs in extreme southeastern and southern Mexico and Belize. 


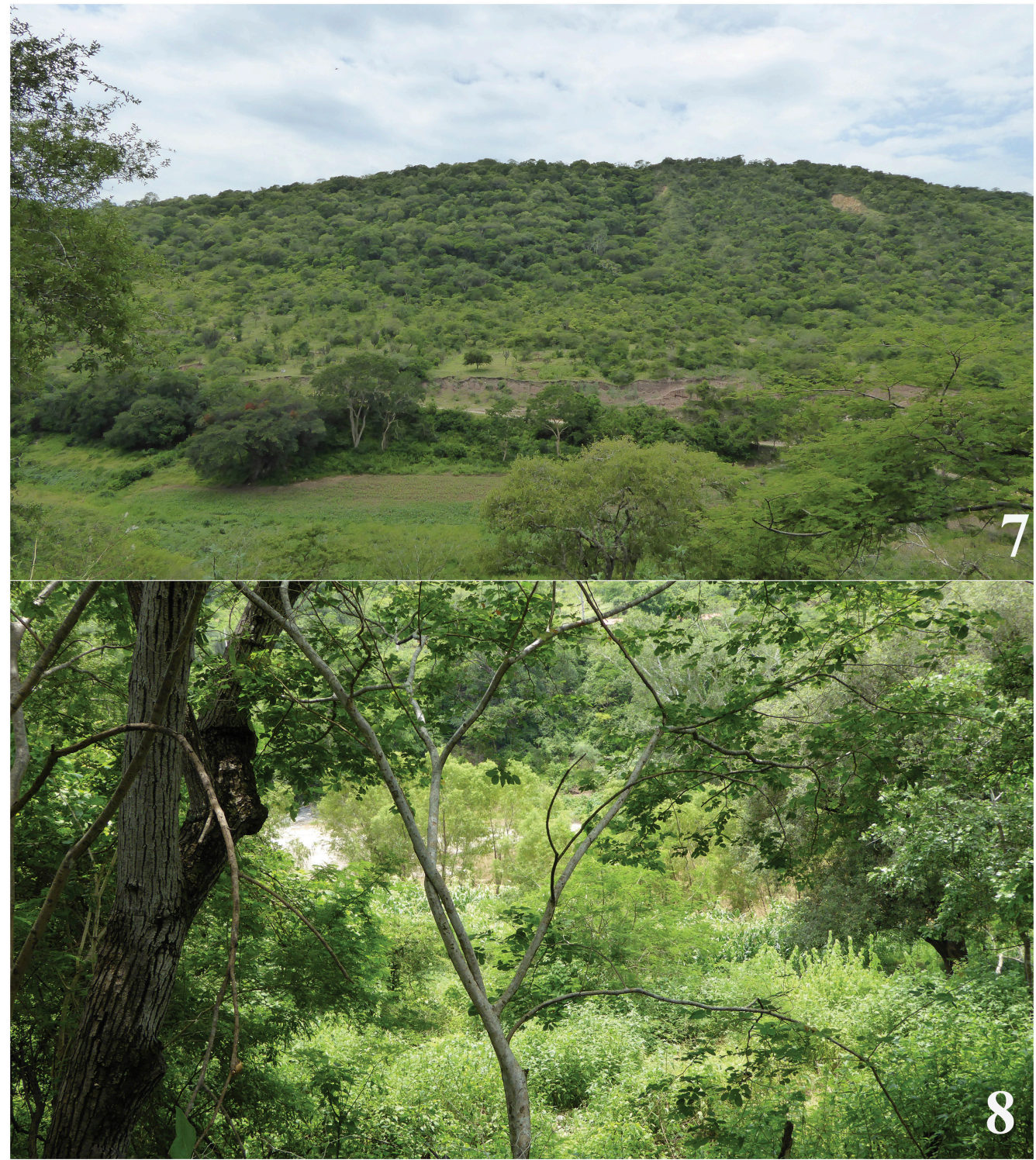

Figs. 7-8. Type locality habitat near Comala, Colima, Mexico of Gymnetis pedroreyesi, new species.

Gymnetis pedroreyesi is most similar to $G$. poecila and occurs partly sympatrically (in the broad sense; we have no Colima records for $G$. poecila) with $G$. poecila in western Mexico. Gymnetis pedroreyesi can be distinguished from $G$. poecila by: 1) the presence in males of diffuse, contrasting light gray or dirty yellow markings on the black pronotum (Figs. 1-2) (pronotum monochromatic black in $G$. poecila); 2) lateral margin of each paramere weakly flared (Fig. 4) versus strongly flared in G. poecila (fig. 311 in Ratcliffe 2018); and
3) smaller size in G. pedroreyesi $(16.0-19.7 \mathrm{~mm}, \overline{\mathrm{x}}=$ $17.5 \mathrm{~mm}, n=24$ ) versus larger in $G$. poecila (18.8-21.3 mm, $\overline{\mathrm{x}}=19.7 \mathrm{~mm}, n=38$ ).

Natural History. Adults of Gymnetis species are primarily diurnal visitors to flowers, ripe fruits, and sap flows, either natural or as a result of beetleinduced abrasion (gumming). Other cetoniines collected at the same locality where $G$. pedroreyesi was collected are Cotinis pauperula Burmeister, Cotinis mutabilis (Gory and Percheron), and Amithao marginicollis (Burmeister). 
The specimens of $G$. pedroreyesi were collected with very ripe banana fruit placed on tree trunks and on banana bait in a bottle trap. The type locality of $G$. pedroreyesi is tropical semi-deciduous forest (Figs. 7-8) where the dominant vegetation is nogal, Juglans major (Torr.) A. Heller (Juglandaceae); cobano, Swietenia humilis Zuccarini (Meliaceae); parota, Enterolobium cyclocarpum (Jacq.) Griseb. (Fabaceae); huizache, Goldmania foetida (Jacq.) Standley (Fabaceae); mezquite, Prosopis juliflora (Sw.) DC (Fabaceae); tepemezquite, Lysiloma divaricatum (Jacq.) J. F. Macbr (Fabaceae); guamuchil, Pithecellobium dulce Bentham (Fabaceae); higuera, Ficus petiolaris Kunth (Moraceae); rosa morada, Tabebuia pentaphylla (L.) Hemsl. (Bignoniaceae); primavera, Tabebuia donnell-smithii Rose (Bignoniaceae); guasima, Guazuma ulmilfolia Lam. (Malvaceae); ciprés, Cupressus sp. (Cupressaceae); fresno, Fraxinus sp. (Oleaceae); nance, Byrsonima crassifolia (L.) Kunth (Malphigiaceae); and chico zapote, Achras zapota L. (Sapotaceae) (Martínez 1979; Morales et al. 1990; Rzedowski and Huerta 1994; Sociedad Botánica de México 1987; Tropicos.org 2019). Climate in the vicinity of the type locality is warm subtropical with annual average precipitation of $1,163 \mathrm{~mm}$ and temperature of $23-27{ }^{\circ} \mathrm{C}$.

\section{Key to the Mexican Species of Adult Gymetis MacLeaY}

1. Pronotum monochromatic black ........... 2

1'. Pronotum with contrasting colors, spots, flecks, or bands ........................ 4

2. Lateral marginal bead of elytra yellow ..... G. ramulosa Bates

$2^{\prime}$. Lateral marginal bead of elytra black ......... 3

3. Body length equals $16.0-19.7 \mathrm{~mm} . . . . . . .$. ...G. pedroreyesi Ratcliffe and Nogueira, new species (in part, female)

$3^{\prime}$. Size larger, body length equals $18.8-21.0 \mathrm{~mm} .$. G. poecila Schaum

4. Abdominal sternites, at least in part, with metallic bronze, metallic green, metallic reddish purple, or metallic reddish brown reflection . ...

4'. Abdominal sternites lacking metallic reflection, shiny areas, if present, black, brown, or reddish brown, especially in females .................. 6

5. Elytra with bold pattern of alternating black and yellow bands radiating laterally from diffuse orange area at middle

G. stellata (Latreille)

5'. Elytra orange and/or yellow intermixed with mottled, irregularly diffuse, brown or black flecks and with 2 irregular fields of bright yellow, 1 on disc at middle and other near apex

\section{G. cupriventris kerremansi}

Neervoort van de Poll

6. Pronotum and/or disc of elytra predominantly light to dark orange or reddish orange mixed with black bands, spots, or flecks; elytral margin next to marginal bead without contrasting, isolated, reddish orange spots .................................... 7

6'. Pronotum and/or disc of elytra predominantly light or dark brown, light or dark gray, black, yellow, various shades of olive, ochre, or chalky white mixed with black bands, spots, or flecks; elytral margin next to marginal bead with or without small, orange or reddish orange spots ................. 9

7. Lateral marginal bead of elytra orange ..... G. bajula wollastonii Schaum

7'. Lateral marginal bead of elytra dark gray, dark brown, or black .................... 8

8. Elytral black markings soft-edged with cloudings of light gray surrounding and/or among most soft-edged black marks

G. vandepolli Bates

8'. Elytral black markings hard-edged, lacking cloudings of light gray among markings. Orange phase of

G. radiicollis Burmeister (in part)

9. Pronotum and/or elytra predominantly light or dark brown or gray with black markings on disc and/or adjacent to lateral margin .............................. 10

9'. Pronotum and/or elytra black with yellow, ochre, or light to dark orange markings on disc and/or adjacent to lateral margin ........... 11

10. Mesometasternal process, in lateral view, projecting strongly or almost vertically downwards from ventral axis of body. Elytral apices rounded, not produced into short, spine-like projection

G. coturnix Burmeister

10'. Mesometasternal process, in lateral view, projecting obliquely forward and downwards from ventral axis of body at $33-45^{\circ}$. Elytral apices strongly produced into short, spine-like projection .

G. difficilis Burmeister

11. Mesometasternal process, in lateral view, projecting strongly to almost vertically downwards from ventral axis of body ................... 12

11'. Mesometasternal process, in lateral view, projecting obliquely forward and downwards from ventral axis of body at $33-45^{\circ}$ 13

12. Lateral marginal bead of elytra yellow ..... G. sallei Schaum

12'. Lateral marginal bead of elytra black. Yellow phase of. $G$, radiicollis Burmeister (in part) 
13. Mesepimeron completely yellow or with trace of black on posterior margin

G. thula Ratcliffe

13'. Mesepimeron completely black ...G. pedroreyesi Ratcliffe and Nogueira, new species (in part, male)

\section{References Cited}

Martínez, M. 1979. Catálogo de Nombres Vulgares y Científicos de Plantas Mexicanas. Fondo de Cultura Economica. Mexico City, Mexico, $1247 \mathrm{pp}$.

Morales, J. B., and L. A. Perez Jimenez. 1990. Manual de Identificación de Árboles de Selva Baja Mediante Cortezas. Universidad Nacional Autonoma de México, México, DF, Mexico, 83 pp.

Ratcliffe, B. C. 2018. A monographic revision of the genus Gymnetis (Coleoptera: Scarabaeidae: Cetoniinae). Bulletin of the University of Nebraska State Museum 31: 1-250.

Ridgway, R. 1912. Color standards and color nomenclature. With fifty-three colored plates and eleven hundred and fifteen named colors. archive.org/ details/mobot31753002026018/page/3 (accessed 1 May 2019).

Rzedowski, J., and L. Huerta M. 1994. Vegetación de México. Editorial Limusa, Noriega Editores, Mexico DF, Mexico, 432 pp.

Smithe, F. B. 1975. Naturalist's Color Guide. The American Museum of Natural History, New York, NY, 229 pp.

Sociedad Botánica de México. 1987. Guías Botánicas de Excursiones en México, Volume 8. X Congreso Mexicano de Botánica, Sociedad Botánica de México, México, DF, Mexico.

Tropicos.org. 2012. Missouri Botanical Garden. www. tropicos.org (accessed 16 May 2019).

Wheeler, Q. D., and N. I. Platnick. 2000. The phylogenetic species concept (sensu Wheeler and Platnick) [pp. 55-69]. In: Species Concepts and Phylogenetic Theory: A Debate (Q. D. Wheeler and R. Meier, editors). Columbia University Press, New York, 245 pp.

(Received 20 August 2019; accepted 2 January 2020. Publication date 25 March 2020.) 